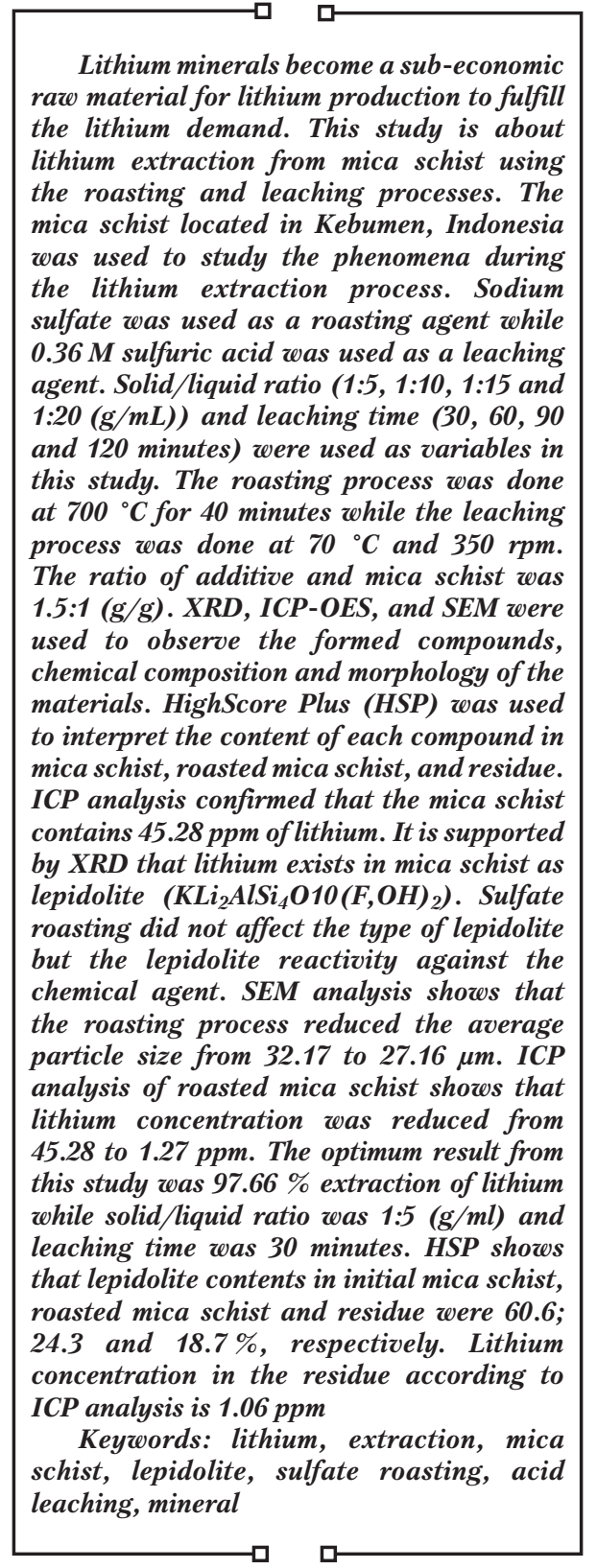

UDC 622

DOI: $10.15587 / 1729-4061.2021 .231071$

\section{THE USE OF MICA SCHIST FROM INDONESIA AS RAW MATERIAL FOR LITHIUM EXTRACTION PROCESS USING SULFATE ROASTING AND ACID LEACHING}

\author{
Nadia Chrisayu Natasha \\ Corresponding author
}

Master of Engineering, Junior Researcher*

E-mail: nadia_natasha90@yahoo.com

Latifa Hanum Lalasari

Doctor of Engineering, Senior Researcher*

Lia Andriyah

Master of Physical and Mathematical Sciences, Junior Researcher*

Tri Arini

Master of Engineering, Junior Researcher*

Fariza Yunita

Master of Engineering, Junior Researcher*

Didied Haryono

Associate Professor

Advance Materials and Tomography Laboratory**

Fani Rinanda

Bachelor of Engineering, Undergraduate Student

Department of Metallurgy Engineering**

* Research Center for Metallurgy and Material Indonesian Institute of Sciences (LIPI)

Building 470, Puspiptek Serpong, Tangerang Selatan, Banten, Indonesia, 15314

**Universitas Sultan Ageng Tirtayasa Jl. Jenderal Sudirman Km 3, Kota Cilegon, Banten
Received date: 07.05.2021 Accepted date: 08.06.2021 Published date: 18.06 .2021
How to Cite: Natasha, N. C., Lalasari, L. H., Andriyah, L., Arini, T., Yunita, F. E., Haryono, D., Rinanda, F. (2021). The use of mica schist from Indonesia as raw material for lithium extraction process using sulfate roasting and acid leaching. Eastern-European Journal of Enterprise Technologies, 3 (6 (111)), 80-88. doi: https://doi.org/10.15587/1729-4061.2021.231071

\section{Introduction}

Lithium is one of the important components contained in lithium batteries and other commercial products such as pharmaceuticals, ceramic and aluminum industry [1]. Due to low density, high electrochemical standard potential and other unique properties, the utilization of lithium in many applications increases annually. There is a prediction that the consumption of lithium in the world will increase by around $60 \%$ in the next 5 years. This is caused by upcoming hybrid vehicles and portable electronic devices, which use lithium batteries, developed rapidly [2]. Brine water is the primary source of lithium because it contains approximately $0.1 \% \mathrm{Li}$, characterized by large reserves, low-cost production and simple processing [2,3]. However, to fulfill the demand for lithium, which is predicted to increase sharply, another lithium source is urgently needed. Lithium mineral processing is more difficult and needs a higher production cost than brine water processing. In general, lithium mineral processing is divided into four stages that are comminution, beneficiation, roasting and leaching. Roasting using additives is an important thing because it can reduce the time and temperature of the roasting process [4]. Prior to roasting at high temperature, lithium ore is added with additives such as sodium sulfate, potassium sulfate or calcium carbonate to convert the compounds contained in lithium ore to become soluble species [5].

Lepidolite is one of several potential lithium minerals in ore that has been developed to produce lithium in the form of lithium carbonate [5]. Lepidolite is a monoclinic system 
that has a theoretical formula of $\mathrm{KLi}_{2} \mathrm{AlSi}_{4} \mathrm{O}_{10}(\mathrm{~F}, \mathrm{OH})_{2}$ and comprises 3.0-7.7 wt \% $\mathrm{Li}_{2} \mathrm{O}[3,6]$. Sulfate acid and lime methods are the two most important processes for lithium extraction from lepidolite [1]. There are some researchers that studied lithium extraction from lithium minerals especially lepidolite. The paper [1] performed the lithium extraction process from lepidolite $(2 \mathrm{wt} \% \mathrm{Li})$ by sulfation roasting followed by water leaching and got $91.61 \%$ lithium extraction efficiency. Besides that, $81 \%$ Li recovery was achieved from a research about lithium recovery from lepidolite $(1.55 \mathrm{wt} \% \mathrm{Li})$ with iron sulfide roasting and water leaching, which has been done in [7]. The paper [3] carried out a research about lithium recovery from lepidolite concentrate $\left(4.59 \mathrm{wt} \% \mathrm{Li}_{2} \mathrm{O}\right)$, roasted with three different potassium compounds followed by water leaching and got $92.78 \% \mathrm{Li}$ extraction. Unfortunately, those studies only used water as a leaching agent while one of the most important processes to extract lithium from lepidolite is sulfate acid.

Therefore, studies are devoted to selecting the best variables to perform the decomposition process, using different leaching agents in the leaching process and sometimes carrying out beneficiation prior to the roasting and leaching processes. The variables that can be chosen for the decomposition process are calcination at high temperature and roasting process with additives at a lower temperature. The function of the beneficiation process is to upgrade the lithium concentration contained in raw material. Upgrading the lithium concentration prior to the roasting and leaching processes is used for removing the impurities that interfere with the lithium extraction process. The beneficiation processes that can be used for upgrading the lithium concentration are dense media separation, magnetic separation and flotation. Leaching agents that are mainly used to extract lithium are water and acid.

\section{Literature review and problem statement}

The paper [8] presents the results of research about the effects of mechanical activation on lithium extraction from a lepidolite ore concentrate. The time effect on grinding to lithium extraction percentage is shown. This study used grinding, acid leaching using sulfuric acid for 4 hours and water leaching process using a thermostatic orbital shaker $(100 \mathrm{rpm})$ at $80^{\circ} \mathrm{C}$ for 4 hours, as stages to extract lithium from lepidolite. It is concluded that agglomeration increases along with increasing grinding time. This study got $82 \%$ lithium extraction while the grinding process was done for 10 minutes and the lithium extraction increased to $87 \%$ while the grinding process was done for 30 minutes. The grinding process should be done in less than 30 minutes to get the best result. Besides that, this study also told that the recovery did not increase significantly while increasing leaching time to 4 hours. There were unresolved issues related to the processing time and cost. This is caused by the fact that the paper used 4 hours in acid leaching and 4 hours in water leaching. All this suggests that it is advisable to conduct a study on using a leaching time of less than 4 hours and grinding time less than 30 minutes.

The paper [1] presents the results of research about the extraction of lithium from lepidolite by sulfation roasting and water leaching. The temperature effect on the roasting process to the presents of lepidolite and lithium extraction percentage is shown. This study used roasting using $\mathrm{Na}_{2} \mathrm{SO}_{4}$ and/or other additions $\left(\mathrm{K}_{2} \mathrm{SO}_{4}, \mathrm{CaO}\right)$ at various temperatures for 30 minutes and water leaching at room temperature for 30 minutes. This study got $91.61 \%$ lithium extraction while carrying out the roasting process at $850{ }^{\circ} \mathrm{C}$ for 30 minutes, water leaching for 30 minutes and the lepidolite/ $\mathrm{Na}_{2} \mathrm{SO}_{4} / \mathrm{K}_{2} \mathrm{SO}_{4} / \mathrm{CaO}$ ratio was 1:0.5:0.1:0.1. The result of the leaching process shows that the efficiency of lithium extraction increased significantly during the roasting process above $750{ }^{\circ} \mathrm{C}$ when using other additives. There were unresolved issues related to processing time and cost. This is caused by the fact that the paper used $850{ }^{\circ} \mathrm{C}$ in roasting and 30 minutes in water leaching. This approach was used in [9], which showed that the roasting process with $\mathrm{K}_{2} \mathrm{SO}_{4}$ needs a higher temperature and there will be a reaction that is harmful to lithium extraction. All this suggests that it is advisable to conduct a study to remove the additives, especially $\mathrm{K}_{2} \mathrm{SO}_{4}$, to use a lower temperature. This will save energy and reduce the operation cost automatically.

The paper [7] presents the results of research about the extraction of lithium from lepidolite via iron sulfide roasting and water leaching. The effect of roasting temperature and time, leaching temperature and solid/liquid ratio on lithium extraction percentage from lepidolite concentrate is shown. This study used the roasting process with $\mathrm{FeS}-\mathrm{CaO}$ at various temperatures, then water leaching with various temperatures and solid/liquid ratios. This study got $81 \%$ Li recovery in the roasting process at $750{ }^{\circ} \mathrm{C}$ for 1.5 hours and water leaching at $50{ }^{\circ} \mathrm{C}$ for 2 hours with a solid/liquid ratio $>1: 5$. There were unresolved issues related to gas emission and energy consumption. This approach was used in [2], which showed that $\mathrm{SO}_{2}$ will be produced from leaching the roasted product but it can be avoided with acid leaching. All this suggests that it is advisable to conduct a study to use the acid leaching process and lower roasting temperature.

The paper [10] presents the results of research about mineral-metallurgical processes for lithium recovery from pegmatite ore. The effect of calcination temperature, digestion temperature and acid concentration is shown. This study used calcination, sulfuric digestion, water leaching and acid leaching processes. This study got the best calcination temperature of $800{ }^{\circ} \mathrm{C}$ for 13 hours, the best digestion temperature with $\mathrm{H}_{2} \mathrm{SO}_{4}$ of $200{ }^{\circ} \mathrm{C}$ for 30 minutes and the best acid concentration in the leaching process of $300 \mathrm{~g} / \mathrm{L} \mathrm{HCl}$ at $90{ }^{\circ} \mathrm{C}$ for 4 hours. There were unresolved issues related to the processing time and energy consumption. This approach was used in [11], which showed that the calcination process needs a higher temperature than the roasting process with additives. All this suggests that it is advisable to conduct a study to use the roasting process with additives in activating the lepidolite to become an attractive compound against the chemical agent.

The paper [3] presents the results of research about lithium recovery from lepidolite roasted with potassium compounds. The effect of different types of additives, additive/ ore mass ratios, roasting temperatures, roasting time and $\mathrm{pH}$ of leaching solutions on the lithium extraction process is shown. This study used the roasting process with three different potassium compounds, water leaching at $90{ }^{\circ} \mathrm{C}$ for 3 hours and acid leaching with different concentrations using $\mathrm{H}_{2} \mathrm{SO}_{4}$ at $40{ }^{\circ} \mathrm{C}$ for 2 hours. This study got $92.78 \%$ of lithium extraction using $\mathrm{K}_{2} \mathrm{SO}_{4}$ mixed with $\mathrm{KOH}$ as additives at $900{ }^{\circ} \mathrm{C}$ for 2 hours in the roasting process, water leaching at $90{ }^{\circ} \mathrm{C}$ for 3 hours and acid leaching while the 
$\mathrm{pH}$ was 1 . There were unresolved issues related to energy consumption and processing time. This approach was used in [9], which showed that the roasting process with $\mathrm{K}_{2} \mathrm{SO}_{4}$ needs a higher temperature. All this suggests that it is advisable to conduct a study to use $\mathrm{Na}_{2} \mathrm{SO}_{4}$ as an alternative additive to reduce the temperature of the roasting process.

The paper [12] presents the results of research about the extraction of lithium from $\beta$-spodumene using sodium sulfate solution. The effect of $\mathrm{Na}_{2} \mathrm{SO}_{4}$ /ore mass ratio, additive/ore mass ratio, roasting temperature, particle size, liquid/solid (L/S) ratio, and leaching time is shown. This study used the leaching process with the mixture of sodium sulfate solution and $\mathrm{CaO}$ or sodium sulfate solution and $\mathrm{NaOH}$. The leaching process was done at various temperatures for 3 hours and $2.7 \pm 0.1 \mathrm{MPa}$. This study got $93.3 \%$ of lithium extraction percentage using the mixture of sodium sulfate solution and $\mathrm{CaO}$ and $90.7 \%$ using the mixture of sodium sulfate solution and $\mathrm{NaOH}$. The operating conditions for those results were $\mathrm{Na}_{2} \mathrm{SO}_{4}$ /additive $(\mathrm{CaO}$ or $\mathrm{NaOH}$ )/ore mass ratio=9:0.4:20, leaching temperature of $230{ }^{\circ} \mathrm{C}$ for 3 hours; $\mathrm{L} / \mathrm{S}$ ratio was $7.5 \mathrm{~mL} / \mathrm{g}$ and particle size (D 90) was $39.233 \mu \mathrm{m}$. This study told that $\mathrm{NaOH}$ addition to the leaching process leads to agglomeration and decreased extraction efficiency. There were unresolved issues related to the less efficient process. All this suggests that it is advisable to conduct a study to perform the leaching process without additives especially $\mathrm{NaOH}$.

The paper [2] presents the results of research about the recovery of valuable metals from lepidolite by atmosphere leaching and kinetics in lithium dissolution. The effect of acid concentration, L/S ratio, leaching temperature, particle size, and reaction time on lithium extraction is shown. This study used acid leaching with aqueous sulfuric acid at various temperatures. This study got $94.18 \%$ at the $\mathrm{L} / \mathrm{S}$ ratio of 2.5:1, acid/lepidolite mass ratio of 1.2:1, particle size $<180 \mu \mathrm{m}$, temperature of $411 \mathrm{~K}$ and reaction time of 10 hours. This study used high temperature $(411 \mathrm{~K})$ and a long time (10 hours) for the leaching process. There were unresolved issues related to the energy consumption due to the high temperature in the leaching process and processing time. This approach was used in [6,13]. According to [14], the temperature of $70{ }^{\circ} \mathrm{C}$ and pressure of $31.202 \mathrm{kPa}$ show the specific volume of saturated liquid of $0.001023 \mathrm{~m}^{3} / \mathrm{kg}$ and specific volume of saturated vapor of $5.0396 \mathrm{~m}^{3} / \mathrm{kg}$. In addition, the variables used in that study were $138^{\circ} \mathrm{C}$ and $100 \mathrm{kPa}(1 \mathrm{~atm})$ so there must be a lot of vaporized elements.

All this suggests that it is advisable to conduct a study to perform the leaching process at lower temperature and shorter time. Based on those references, the authors decided to use the roasting process with $\mathrm{Na}_{2} \mathrm{SO}_{4}$ to reduce the roasting time and acid leaching without adding the additives at lower temperature. Several variations as done in the previous study such as L/S ratio and leaching time were also done in this study.

\section{The aim and objectives of the study}

The aim of the study is to utilize and explore the potential of local mineral from Indonesia to perform lithium extraction using sulfate roasting and acid leaching with the variations of solid/liquid ratio and leaching time.

To achieve this aim, the following objectives are accomplished:
- to study the initial characteristics of mica schist;

- to find out the effect of sulfate roasting on the characteristics of mica schist;

- to observe the effect of acid leaching on the characteristics of filtrate and residue then determine the optimal operating conditions from this study.

\section{Materials and methods of the study}

Mica schist that contains lepidolite from Kebumen, Central Java, Indonesia was used as a raw material. Sodium sulfate $\left(\mathrm{Na}_{2} \mathrm{SO}_{4}\right)\left(\right.$ Merck $\left.{ }^{\circledR}\right)$ was used as a roasting agent and sulfate acid $\left(\mathrm{H}_{2} \mathrm{SO}_{4}\right)$ (Merck $\left.{ }^{\circledR}\right)$ as a leaching agent. The steps were done in the same way that has been done by the authors in [15]. The first step was crushing mica schist using a jaw crusher then milling using a disc mill until the particle size was -100 mesh. Then the raw material was analyzed using inductively coupled plasma - optical emission spectroscopy (ICP-OES) (Agilent technologies $700 \mathrm{Se}-$ ries) to determine the initial chemical composition, X-ray diffraction (XRD) (Shimadzu XRD-7000) to find out the compounds contained in mica schist and scanning electron microscopy (SEM) (JEOL-JSM 6390A) to know the morphology and particle size of mica schist.

The second step was adding sodium sulfate to mica schist with the ratio of $1.5: 1(\mathrm{~g} / \mathrm{g})$, then roasting at $700{ }^{\circ} \mathrm{C}$ for 40 minutes in a carbolite furnace to perform the roasting process. After that, the roasted mica schist was analyzed using X-ray diffraction (XRD) (Shimadzu XRD-7000) to determine the compounds contained in roasted mica schist, inductively coupled plasma - optical emission spectroscopy (ICP-OES) (Agilent technologies 700 Series) to determine the chemical composition of roasted mica schist and scanning electron microscopy (SEM) (JEOL-JSM 6390A) to determine the morphology of roasted mica schist. Those analyses were done to observe the roasting process effect on the compounds, chemical composition and morphology of mica schist.

The third step was leaching using $0.36 \mathrm{M}$ sulfuric acid at $70{ }^{\circ} \mathrm{C}$ and $350 \mathrm{rpm}$ with various variables. There are 2 variables, namely the solid/liquid ratio $(1: 5,1: 10,1: 15,1: 20(\mathrm{~g} / \mathrm{ml}))$ and leaching time $(30,60,90$ and 120 minutes). The leaching process was done using a hot plate, reflux and magnetic stirrer. The filtration process was done as the last step to separate the residue and the filtrate. The residue and the filtrate from this step were analyzed using X-ray diffraction (XRD) (Shimadzu XRD7000 ), inductively coupled plasma - optical emission spectroscopy (ICP-OES) (Agilent technologies 700 Series) and scanning electron microscopy (SEM) (JEOL-JSM 6390A).

\section{Results of determining the lithium percent extraction}

\section{1. Initial characteristics of mica schist}

5. 1. 1. Chemical composition of mica schist

Mica schist powder was analyzed using ICP-OES to know its chemical composition and confirm that lithium is contained in it. The initial chemical composition of mica schist can be seen in Table 1 .

Based on Table 1, mica schist from Kebumen, Central Java, Indonesia consists of aluminum, calcium, iron, potassium, lithium, magnesium, sodium and silicon. There are 
some elements that have a high content, i.e. calcium (Ca) $40.31 \mathrm{ppm}$ and lithium (Li) $45.28 \mathrm{ppm}$. Table 1 also shows that mica schist has some minor elements, i.e. aluminum (Al) $8.78 \mathrm{ppm}$, silicon ( $\mathrm{Si}) 8.91 \mathrm{ppm}$ and sodium $(\mathrm{Na}) 1.71 \mathrm{ppm}$.

Table 1

Chemical composition of mica schist from Kebumen, Central Java, Indonesia

\begin{tabular}{|c|c|c|}
\hline No. & Element & Concentration (ppm) \\
\hline 1 & $\mathrm{Al}$ & 8.78 \\
\hline 2 & $\mathrm{Ca}$ & 40.31 \\
\hline 3 & $\mathrm{Fe}$ & 13.18 \\
\hline 4 & $\mathrm{~K}$ & 10.99 \\
\hline 5 & $\mathrm{Li}$ & 45.28 \\
\hline 6 & $\mathrm{Mg}$ & 12.83 \\
\hline 7 & $\mathrm{Na}$ & 1.71 \\
\hline 8 & $\mathrm{Si}$ & 8.91 \\
\hline
\end{tabular}

\section{1. 2. Compounds in mica schist}

The XRD patterns of mica schist are shown in Fig. 1. Fig. 1 tells that the compounds of mica schist are lepidolite $\left(\mathrm{K}(\mathrm{Li}, \mathrm{Al})_{3}(\mathrm{Si}, \mathrm{Al})_{4} \mathrm{O}_{10}(\mathrm{~F}, \mathrm{OH})_{2}\right)$, low albite $\left(\mathrm{Na}\left(\mathrm{AlSi}_{3}\right) \mathrm{O}_{8}\right)$, quartz $\left(\mathrm{SiO}_{2}\right)$ and anorthite $\left(\mathrm{Al}_{2} \mathrm{CaSi}_{2} \mathrm{O}_{8}\right)$.

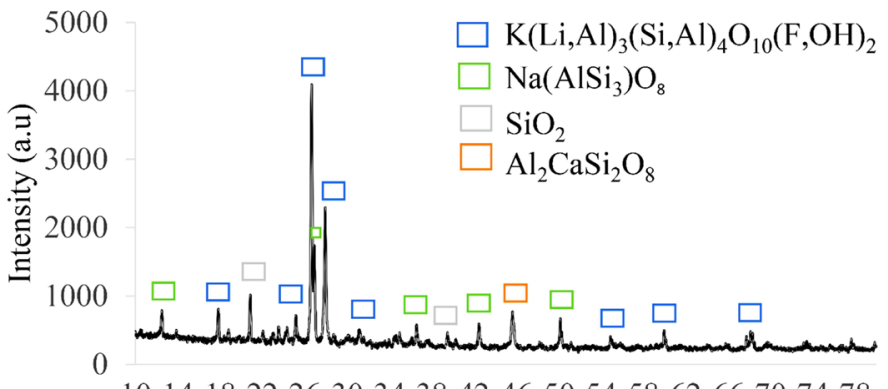

101418222630343842465054586266707478 2 Theta $\left({ }^{0}\right)$

Fig. 1. XRD patterns of mica schist

The strongest peak of lepidolite compound in Fig. 1 is located at $27^{\circ}$, anorthite at $46^{\circ}$, albite at $27.1^{\circ}$ and quartz at $21^{\circ}$ in $2 \theta$-scale. The XRD patterns were interpreted by HighScore Plus (HSP) version 3.0e (3.0.5). HighScore Plus (HSP) application can determine the level of compounds contained in mica schist. The level of compounds in mica schist is shown in Table 2.

Table 2 shows that mica schist is dominated by lepidolite $(60.6 \%)$, followed by anorthite $(31.3 \%)$. On the other hand, the minor compounds in mica schist are albite $(7.2 \%)$ and quartz (0.9\%).

Level of compounds in mica schist based on HighScore Plus (HSP) application

\begin{tabular}{|c|c|c|c|c|c|}
\hline No. & Ref. Code & $\begin{array}{c}\text { Com- } \\
\text { pound } \\
\text { Name }\end{array}$ & $\begin{array}{c}\text { Scale } \\
\text { Factor }\end{array}$ & $\begin{array}{c}\text { Content } \\
(\%)\end{array}$ & Chemical formula \\
\hline 1 & $98-003-4184$ & Lepidolite & 0.132 & 60.6 & $\mathrm{~K}(\mathrm{Li}, \mathrm{Al})_{3}\left(\mathrm{Si}, \mathrm{Al}_{4} \mathrm{O}_{10}(\mathrm{~F}, \mathrm{OH})_{2}\right.$ \\
\hline 2 & $98-007-7421$ & Albite & 0.251 & 7.2 & $\mathrm{Na}_{\left(\mathrm{AlSi}_{3}\right) \mathrm{O}_{8}}$ \\
\hline 3 & $98-008-9277$ & Quartz & 0.653 & 0.9 & $\mathrm{SiO}_{2}$ \\
\hline 4 & $98-006-7953$ & Anorthite & 0.322 & 31.3 & $\mathrm{Al}_{2} \mathrm{CaSi}_{2} \mathrm{O}_{8}$ \\
\hline
\end{tabular}
lithium (1.27 ppm) is a minor element.

Table 2

5. 2. 2. Compounds of roasted mica schist $\mathrm{XRD}$ analysis was done to know the effect of the roasting process on each compound contained in mica schist. The XRD patterns of roasted mica schist are shown in Fig. 3.

The products of this roasting process are lepidolite $\left(\mathrm{K}(\mathrm{Li}, \mathrm{Al})_{3}(\mathrm{Si}, \mathrm{Al})_{4} \mathrm{O}_{10}(\mathrm{~F}, \mathrm{OH})_{2}\right)$, albite $\left(\mathrm{Na}\left(\mathrm{AlSi}_{3}\right) \mathrm{O}_{8}\right)$, forsterite $\left(\mathrm{Mg}_{2} \mathrm{SiO}_{4}\right)$, dipotassium diferrate (III) $\left(\mathrm{Fe}_{2} \mathrm{~K}_{2} \mathrm{O}_{4}\right)$ and dicalcium silicate $\left(\mathrm{Ca}_{2} \mathrm{SiO}_{4}\right)$. The strongest peak of the lepidolite compound in Fig. 3 is 
located at $33^{\circ}$ while albite at $27^{\circ}$ in $2 \theta$-scale. HSP application was also used to determine the level of each compound in roasted mica schist (Table 4).

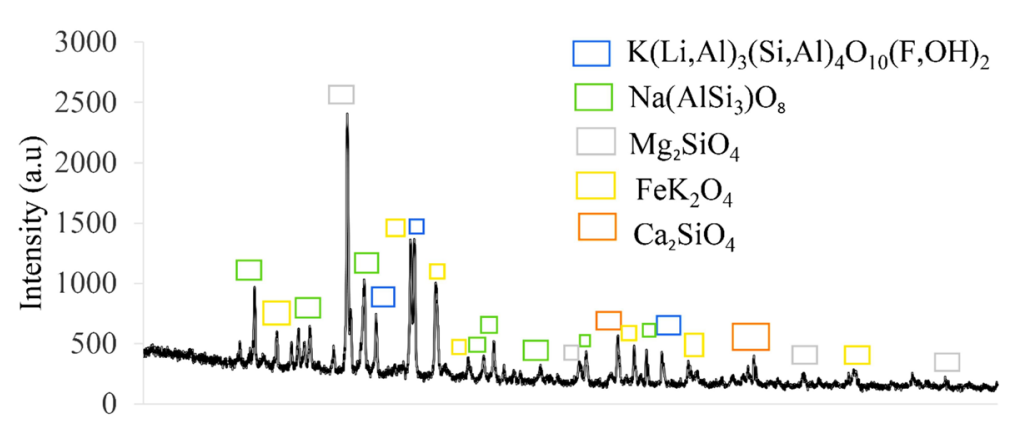

$\begin{array}{llllllllllllllllll}10 & 14 & 18 & 22 & 26 & 30 & 34 & 38 & 42 & 46 & 50 & 54 & 58 & 62 & 66 & 70 & 74 & 78\end{array}$ 2 Theta $\left({ }^{0}\right)$

Fig. 3. XRD patterns of roasted mica schist

Level of each compound in roasted mica schist

\begin{tabular}{|c|c|c|c|c|c|}
\hline No. & Ref. Code & $\begin{array}{c}\text { Compound } \\
\text { Name }\end{array}$ & $\begin{array}{c}\text { Scale } \\
\text { Factor }\end{array}$ & $\begin{array}{c}\text { Content } \\
(\%)\end{array}$ & Chemical formula \\
\hline 1 & $98-003-4337$ & Lepidolite & 0.157 & 24.3 & $\mathrm{~K}(\mathrm{Li}, \mathrm{Al})_{3}\left(\mathrm{Si}, \mathrm{Al}_{4}\right)_{10}(\mathrm{~F}, \mathrm{OH})_{2}$ \\
\hline 2 & $98-020-1919$ & Albite & 0.242 & 2.8 & $\mathrm{Na}_{\left(\mathrm{AlSi}_{3}\right) \mathrm{O}_{8}}$ \\
\hline 3 & $98-007-7536$ & Forsterite & 0.107 & 2.3 & $\mathrm{Mg}_{2} \mathrm{SiO}_{4}$ \\
\hline 4 & $98-009-4467$ & $\begin{array}{c}\text { Dipotassium } \\
\text { Diferrate(III) }\end{array}$ & 0.472 & 33.5 & $\mathrm{Fe}_{2} \mathrm{~K}_{2} \mathrm{O}_{4}$ \\
\hline 5 & $98-008-2996$ & $\begin{array}{c}\text { Dicalcium } \\
\text { Silicate }\end{array}$ & 0.263 & 37.1 & $\mathrm{Ca}_{2} \mathrm{SiO}_{4}$ \\
\hline
\end{tabular}

Table 4 shows that the contents of lepidolite, albite, forsterite, dipotassium diferrate (III) and dicalcium silicate are $24.3 ; 2.8 ; 2.3 ; 33.5$ and $37.1 \%$, respectively. The most dominant compound based on Table 4 is dicalcium silicate while forsterite is the compound that has the lowest content.

\section{2. 3. Morphology of roasted mica schist}

SEM image of the product roasted with sodium sulfate at $700{ }^{\circ} \mathrm{C}$ for 40 minutes is shown in Fig. 4. The purpose of this analysis is to know the effect of the roasting process on the morphology and particle size of roasted mica schist.

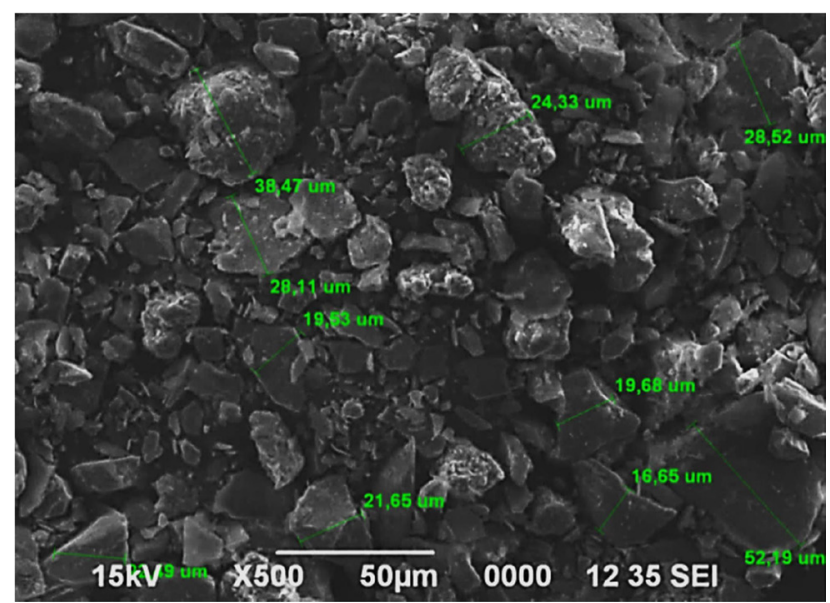

Fig. 4. Morphology of roasted mica schist
Based on Fig. 4, the particle shape of roasted mica schist is the same as the initial shape that is irregular and heterogenic. The roasting process only leads to the average particle size of $27.16 \mu \mathrm{m}$ and the biggest particle size of $52.19 \mu \mathrm{m}$.

\section{3. Characteristics of leaching process product \\ 5. 3. 1. Filtrate}

Table 5 is the table of lithium concentration in the filtrate and lithium extraction percentage with the variables of leaching time and solid/ liquid ratio $(\mathrm{g} / \mathrm{mL})$. According to Table 5 , the optimum lithium extraction percentage is $97.66 \%$ with the leaching conditions of solid/liquid ratio, leaching temperature and leaching time of $1: 5,70{ }^{\circ} \mathrm{C}$ and 30 minutes, respectively. On the other hand, the lowest lithium extraction percentage is $0.97 \%$ with

Table 4 the leaching conditions of solid/liquid ratio, leaching temperature and leaching time of $1: 20,70{ }^{\circ} \mathrm{C}$ and 60 minutes, respectively.

The correlations between solid percentage and lithium extraction percentage from each variable of leaching time can be seen in Fig. 5 . Based on Fig. 5, the best variable of solid percentage is $20 \%$ while the poor variable of solid percentage is $5 \%$.

The best variable to get a higher lithium extraction percentage, based on Fig. 5, is when the leaching process was done for 30 minutes at $70{ }^{\circ} \mathrm{C}$. On the other hand, the poor variable for leaching the roasted mica schist is when the leaching process was done for 90 minutes at $70{ }^{\circ} \mathrm{C}$.

Table 5

Lithium extraction percentage in filtrate

\begin{tabular}{|c|c|c|c|c|}
\hline Sample & $\begin{array}{l}\text { Solid/liquid } \\
\text { ratio }(\mathrm{g} / \mathrm{mL})\end{array}$ & $\begin{array}{c}\text { Percent } \\
\text { solid (\%) }\end{array}$ & $\begin{array}{l}\text { Lithium } \\
\text { concentra- } \\
\text { tion (ppm) }\end{array}$ & $\begin{array}{c}\text { Lithium } \\
\text { extraction } \\
\text { percentage } \\
(\%)\end{array}$ \\
\hline \multirow{4}{*}{ T70W30 } & $1: 20$ & 5 & 1.49 & 3.30 \\
\hline & $1: 15$ & 6.67 & 0.88 & 1.94 \\
\hline & $1: 10$ & 10 & 17.56 & 38.78 \\
\hline & $1: 5$ & 20 & 43.9 & 97.66 \\
\hline \multirow{4}{*}{ T70W60 } & $1: 20$ & 5 & 0.439 & 0.97 \\
\hline & $1: 15$ & 6.67 & 0.70 & 1.55 \\
\hline & $1: 10$ & 10 & 17.56 & 38.78 \\
\hline & $1: 5$ & 20 & 43.9 & 97.66 \\
\hline \multirow{4}{*}{ T70W90 } & $1: 20$ & 5 & 1.32 & 2.9 \\
\hline & $1: 15$ & 6.67 & 8.78 & 19.39 \\
\hline & $1: 10$ & 10 & 0.61 & 1.36 \\
\hline & $1: 5$ & 20 & 35.12 & 77.56 \\
\hline \multirow{4}{*}{ T70W120 } & $1: 20$ & 5 & 2.02 & 4.46 \\
\hline & $1: 15$ & 6.67 & 1.76 & 3.88 \\
\hline & $1: 10$ & 10 & 17.56 & 38.78 \\
\hline & $1: 5$ & 20 & 35.12 & 77.56 \\
\hline
\end{tabular}




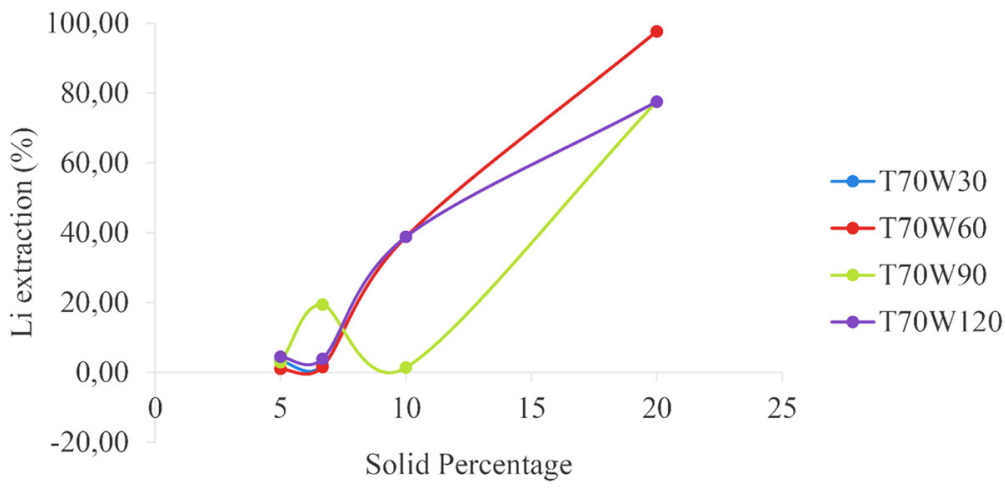

Fig. 5. Correlation chart of solid percentage and lithium extraction percentage in the filtrate

\section{3. 2. Residue}

The residue of the best result from the leaching process was analyzed using XRD to know the remaining compounds in the residue. XRD patterns of the residue can be seen in Fig. 6. Lepidolite $\left(\mathrm{K}(\mathrm{Li}, \mathrm{Al})_{3}(\mathrm{Si}, \mathrm{Al})_{4} \mathrm{O}_{10}(\mathrm{~F}, \mathrm{OH})_{2}\right)$, albite $\left(\mathrm{Na}\left(\mathrm{AlSi}_{3}\right) \mathrm{O}_{8}\right)$, protoenstatite $\left(\mathrm{MgSiO}_{3}\right)$, potassium tetraoxoferrate $\left(\mathrm{FeK}_{2} \mathrm{O}_{4}\right)$ and anorthite, sodian $\left(\mathrm{Al}_{1.52} \mathrm{Ca}_{0.52} \mathrm{Na}_{0.48} \mathrm{Si}_{2.48} \mathrm{O}_{8}\right)$ are the compounds detected in the residue.

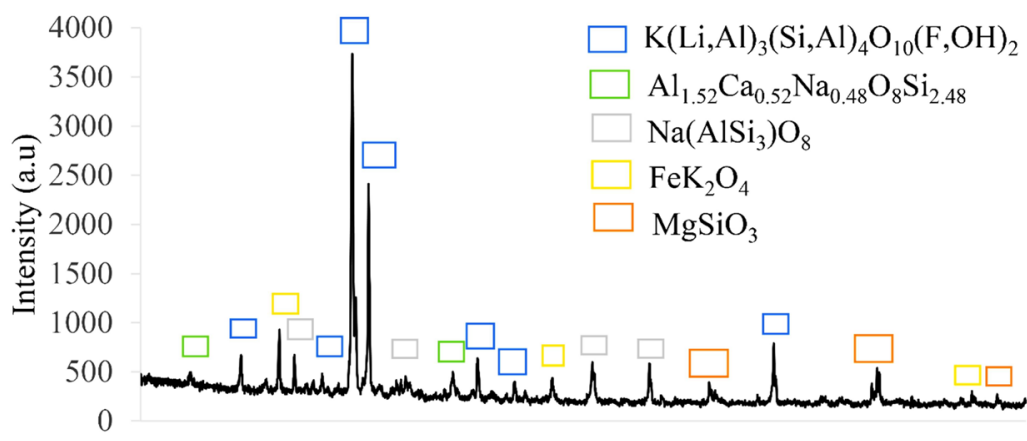

$\begin{array}{llllllllllllllllll}10 & 14 & 18 & 22 & 26 & 30 & 34 & 38 & 42 & 46 & 50 & 54 & 58 & 62 & 66 & 70 & 74 & 78\end{array}$ 2 Theta $\left(0^{\circ}\right)$

Fig. 6. XRD patterns of dry residue

The strongest peak of the lepidolite compound in Fig. 6 is located at $27^{\circ}$ while albite at $46^{\circ}$ in $2 \theta$-scale. The level of each compound in the leaching residue was determined by HSP application (Table 6).

Table 6 tells that the content of each compound is $18.7 \%$ for lepidolite, $8.7 \%$ for albite, $17.5 \%$ for protoenstatite, $18.6 \%$ for potassium tetraoxoferrate and $36.5 \%$ for anorthite, sodian. The residue was analyzed by ICP-OES to confirm the concentration of each element and it can be seen in Table 7.
Table 7

Content of each element in the leaching residue

\begin{tabular}{|c|c|c|}
\hline No. & Element & $\begin{array}{c}\text { Concentration } \\
(\mathrm{ppm})\end{array}$ \\
\hline 1 & $\mathrm{Al}$ & 24.39 \\
\hline 2 & $\mathrm{Ca}$ & 168.54 \\
\hline 3 & $\mathrm{Fe}$ & 15.35 \\
\hline 4 & $\mathrm{~K}$ & 29.92 \\
\hline 5 & $\mathrm{Li}$ & 1.06 \\
\hline 6 & $\mathrm{Mg}$ & 17.30 \\
\hline 7 & $\mathrm{Na}$ & 15.66 \\
\hline 8 & $\mathrm{Si}$ & 23.07 \\
\hline
\end{tabular}

Based on Table 7, the concentration of each element is $24.39 \mathrm{ppm}$ for aluminum, $168.54 \mathrm{ppm}$ for calcium, $15.35 \mathrm{ppm}$ for iron, $29.92 \mathrm{ppm}$ for potassium, $1.06 \mathrm{ppm}$ for lithium, $17.30 \mathrm{ppm}$ for magnesium, $15.66 \mathrm{ppm}$ for sodium and $23.07 \mathrm{ppm}$ for silica. The most dominant element is calcium (168.54 ppm) while the minor element is lithium (1.06 ppm).

\section{Discussion of experimental results}

The chemical composition of raw material in this study can be seen in Table 1 . The analysis shows that lithium is one of the dominant elements while sodium is one of the minor elements in mica schist. Based on Table 1, mica schist is a low-lithium ore because the lithium concentration in mica schist is $<1 \mathrm{wt} \%$ that is $0.005 \mathrm{wt} \%$. On the other hand, lithium concentration in raw ore used in [1] is higher than the lithium concentration in mica schist that is $2 \mathrm{wt} \%$. In addition, lithium concentration in raw ore used in [16] is still higher than the lithium concentration in mica schist that is $0.7 \mathrm{wt} \%$. Nevertheless, lithium was detected in ICP analysis, so it confirms that mica schist from Indonesia can be used as lithium raw material. Table 1 indicates that lithium is bound with aluminum, potassium and silica to form the aluminum silica compound that is lepidolite. XRD analysis was necessary to be done to confirm that lepidolite is contained in mica schist.

The diffraction peaks in the XRD analysis can be seen in Fig. 1. This analysis confirms that lepidolite is contained in mica schist with the highest peak at $27^{\circ}$ in $2 \theta$-scale. There are some compounds that are also contained in mica schist such as albite, silica and an-

Table 6 orthite. The XRD patterns of mica schist from Kebumen, Indonesia are similar to those of lepidolite provided by the Jiangxi Province of China [2]. This indicates that the resources from Indonesia also have the potential as a source of raw material, especially for lithium.

The roasting process with $\mathrm{Na}_{2} \mathrm{SO}_{4}$ as additives was used in this study because it can reduce the process temperature and time compared to

\begin{tabular}{|c|c|c|c|c|c|}
\hline No. & Ref. Code & $\begin{array}{c}\text { Compound } \\
\text { Name }\end{array}$ & $\begin{array}{c}\text { Scale } \\
\text { Factor }\end{array}$ & $\begin{array}{c}\text { Content } \\
(\%)\end{array}$ & Chemical formula \\
\hline 1 & $98-003-0785$ & Lepidolite & 0.247 & 18.7 & $\mathrm{~K}(\mathrm{Li}, \mathrm{Al})_{3}(\mathrm{Si}, \mathrm{Al})_{4} \mathrm{O}_{10}(\mathrm{~F}, \mathrm{OH})_{2}$ \\
\hline 2 & $98-020-1919$ & Albite & 0.123 & 8.7 & $\left.\mathrm{Na}_{(\mathrm{AlSi}}\right)_{3} \mathrm{O}_{8}$ \\
\hline 3 & $98-002-6489$ & Protoenstatite & 0.230 & 17.5 & $\mathrm{MgSiO}_{3}$ \\
\hline 4 & $98-003-2756$ & $\begin{array}{c}\text { Potassium } \\
\text { Tetraoxoferrate }\end{array}$ & 0.030 & 18.6 & $\mathrm{FeK}_{2} \mathrm{O}_{4}$ \\
\hline 5 & $98-003-0124$ & $\begin{array}{c}\text { Anorthite, } \\
\text { sodian }\end{array}$ & 0.146 & 36.5 & $\mathrm{Al}_{1.52} \mathrm{Ca}_{0.52} \mathrm{Na}_{0.48} \mathrm{Si}_{2.48} \mathrm{O}_{8}$ \\
\hline
\end{tabular}


the calcination process [11]. There are two additives that are used frequently in sulfate roasting, namely potassium sulfate $\left(\mathrm{K}_{2} \mathrm{SO}_{4}\right)$ and sodium sulfate $\left(\mathrm{Na}_{2} \mathrm{SO}_{4}\right)$. Sodium sulfate $\left(\mathrm{Na}_{2} \mathrm{SO}_{4}\right)$ was selected as an additive in this study because the roasting process with $\mathrm{K}_{2} \mathrm{SO}_{4}$ needs a higher temperature and there will be a reaction that is harmful to lithium extraction [9].

There are 3 new compounds in Fig. 3 due to the roasting process namely forsterite, dipotassium diferrate(III) and dicalcium silicate. The peak intensity of the lepidolite compound at $28^{\circ}$ in $2 \theta$-scale decreased sharply from $>2,000$ a.u to $<1,000$ a.u if compare Fig. 1,3. Some of the lepidolite peaks that initially appeared in Fig. 1 also disappeared in Fig. 3 due to the roasting process. This confirms with HSP interpretation that the lepidolite concentration reduced from $60.6 \%$ to $24.3 \%$ if compare Table 2 and Table 4 . Based on Fig. 1, roasting of 1.5:1 (g/g) $\mathrm{Na}_{2} \mathrm{SO}_{4} /$ mica schist did not lead to changes in the type of lepidolite and albite. It is similar to the results of [1] that roasted lepidolite will produce the same type of compounds that are lepidolite and albite. On the other hand, the XRD patterns in this study differ from those in [3] because the peak of lepidolite still appears in this study when using $1.5: 1(\mathrm{~g} / \mathrm{g}) \mathrm{Na}_{2} \mathrm{SO}_{4} /$ mica schist. On the other hand, in [3], the peak of lepidolite disappeared when using 1.5:1 (g/g) $\mathrm{K}_{2} \mathrm{SO}_{4} /$ ore. This is due to the ion exchange process so lepidolite is transformed into other compounds, namely $\mathrm{LiKSO}_{4}$, kalsilite, $\mathrm{K}_{2} \mathrm{SO}_{4}$, and $\mathrm{KAlSi}_{2} \mathrm{O}_{6}$. Although lepidolite in this study did not transform to be other compounds, the silicate structure in lepidolite is a reactive form due to the roasting process. The leaching process will be useless if there is no roasting as a preliminary process [9]. The use of excess $\mathrm{Na}_{2} \mathrm{SO}_{4}$ in the roasting process is because lithium extraction is influenced by the mass ratio of $\mathrm{Na}_{2} \mathrm{SO}_{4}$ to lepidolite. The paper [1] tells that lithium extraction increases along with increasing $\mathrm{Na}_{2} \mathrm{SO}_{4} /$ mica schist ratio.

Table 3 shows that the lithium concentration of roasted mica schist decreased sharply from 45.28 to $1.27 \mathrm{ppm}$. The increase in sodium concentration is caused by sodium sulfate addition as a roasting agent to change the character of lepidolite from resistant to reactive against the chemical attack [12]. It is confirmed with the ICP analysis on the concentration of roasted mica schist that sodium concentration increased sharply from 1.71 to $387.59 \mathrm{ppm}$. All element concentrations except lithium increased sharply due to the roasting process if compare Tables 1,3. Aluminum concentration increased from 8.78 to $51.60 \mathrm{ppm}$, calcium concentration increased from 40.31 to $133.19 \mathrm{ppm}$, iron concentration from 13.18 to $49.85 \mathrm{ppm}$, potassium concentration from 10.99 to $42.67 \mathrm{ppm}$, magnesium concentration from 12.83 to $44.56 \mathrm{ppm}$, silica concentration from 8.91 to $12.2 \mathrm{ppm}$.

Fig. 2, 4 tell that the roasting process affects the average particle size and the biggest particle size in mica schist. Based on Fig. 2, 4, the roasting process decreased the average particle size of mica schist from 32.17 to $27.16 \mu \mathrm{m}$. Besides that, the biggest particle size in mica schist decreased from 62.46 to $52.19 \mu \mathrm{m}$. This phenomenon is caused by the internal pressure during the roasting process so it ruined the initial particles to become smaller [17]. On the other hand, the particles in roasted mica schist have the same shape as the particles in raw mica schist. This indicates that the roasting process did not affect the particle shape.

The roasted products were then leached with $0.36 \mathrm{M}$ sulfuric acid at $70{ }^{\circ} \mathrm{C}$ with variations of time and solid/liquid ratio. Sulfuric acid was used as a leaching agent because it is suitable for the extraction process on low-grade ore. In addition, $\mathrm{SO}_{2}$ production can be avoided with acid leaching [2]. The diluted solution for leaching $(0.36 \mathrm{M}$ sulfuric acid) was chosen because it is more economic and environmentally friendly. In addition, this is the continuation study from the previous study [15] where water leaching was used as the second stage but the result is still less than $80 \%$. According to [15], the optimum result of lithium extraction percentage was $70.6 \%$ while using $1: 10(\mathrm{~g} / \mathrm{mL})$ for solid/liquid ratio, ambient temperature and 1 hour for leaching time. So, as the initial study to do acid leaching, the very diluted solution was used.

The leaching process was done using a hot plate, reflux and magnetic stirrer. The reflux was used to avoid the loss of water. According to [14], the temperature of $70{ }^{\circ} \mathrm{C}$ and pressure of $31.202 \mathrm{kPa}$ show the specific volume of saturated liquid of $0.001023 \mathrm{~m}^{3} / \mathrm{kg}$ and specific volume of saturated vapor of $5.0396 \mathrm{~m}^{3} / \mathrm{kg}$. In addition, the variables used in this study were $70{ }^{\circ} \mathrm{C}$ and $100 \mathrm{kPa}(1 \mathrm{~atm})$ so there must be a lot of vaporized elements.

In addition, the acid used in the leaching process at high temperature causes the boiling point to become lower than the water boiling point. This causes the evaporation process to occur faster so the use of reflux is very important. The temperature was studied because leaching temperature influences lithium extraction. Lithium extraction increases along with increasing temperature [18]. Based on [6], lithium extraction percentage increases when the leaching temperature increases from 50 to $85^{\circ} \mathrm{C}$ but the lithium extraction percentage started to decrease at $90{ }^{\circ} \mathrm{C}$. Table 5 shows that the lithium extraction percentage increases when the percent solid increases for each variable. This is caused by the variation of percent solid, which is still lower than its pulp density independent that is $30 \%$ [18]. The same things also happened in [3], the extraction percentage will increase while the solid/liquid ratio increases. The optimum variables to reach the highest lithium extraction percentage according to Table 5 are leaching time of 30 minutes and 1:5 $(\mathrm{g} / \mathrm{mL})$ for solid/liquid ratio.

The optimum lithium extraction percentage in this study is $97.66 \%$. This indicates that almost all lithium elements in mica schist are dissolved to the solution and only a few lithium elements still left inside the roasted mica schist.

To confirm this statement, the XRD analysis of the residue is needed. Fig. 6 shows the XRD patterns of the residue and the peak of lepidolite $\left(\mathrm{K}(\mathrm{Li}, \mathrm{Al})_{3}(\mathrm{Si}, \mathrm{Al})_{4} \mathrm{O}_{10}(\mathrm{~F}, \mathrm{OH})_{2}\right)$, which is still detected in the residue. It is also confirmed by Table 6 that the content of lepidolite is still $18.7 \%$. Compared to the data in Tables 2, 6, lepidolite reduced sharply from 60.6 to $18.7 \%$. This indicates that lepidolite reduced by $41.9 \%$ before the leaching process. The acid leaching process affects not only the lepidolite concentration but also the others. Albite concentration increased from 2.8 to $8.7 \%$ if compare Tables 4,6 . In addition, acid leaching made magnesium, iron and calcium compounds deformed from $\mathrm{Mg}_{2} \mathrm{SiO}_{4}$ to $\mathrm{MgSiO}_{3}, \mathrm{Fe}_{2} \mathrm{~K}_{2} \mathrm{O}_{4}$ to $\mathrm{FeK}_{2} \mathrm{O}_{4}$ and $\mathrm{Ca}_{2} \mathrm{SiO}_{4}$ to $\mathrm{Al}_{1.52} \mathrm{Ca}_{0.52} \mathrm{Na}_{0.48} \mathrm{Si}_{2.48} \mathrm{O}_{8}$, respectively. The concentration of the compounds also changed from 2.3 to $17.5 \%$ for magnesium compounds, 33.5 to $18.6 \%$ for iron compounds and 37.1 to $36.5 \%$ for calcium compounds.

Then, the residue was analyzed with ICP to confirm the lithium content in it. Table 7 shows that the lithium concentration is $1.06 \mathrm{ppm}$. There is no significant change compared to lithium concentration before the leaching pro- 
cess as can be seen in Table 3 . The differentiation of lithium concentration in Tables 3,7 is only $0.21 \mathrm{ppm}$. It is supported by the XRD analysis that lithium is still contained in mica schist. This could happen because the concentration used in this study is low. The previous study tells that the $\mathrm{H}_{2} \mathrm{SO}_{4}$ /ore ratio of $2 \mathrm{~mL} / \mathrm{g}$ produced around $82 \% \mathrm{Li}$ leached and it increases to around $84 \% \mathrm{Li}$ leached when using the $\mathrm{H}_{2} \mathrm{SO}_{4}$ /ore ratio of $3.5 \mathrm{~mL} / \mathrm{g}$ [6]. It can be concluded that the extraction percentage increases along with increasing acid concentration. So, improvisation is still needed to increase acid concentration for acid leaching.

The general chemical reaction that happened in acid leaching is [2]:

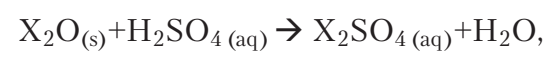

where $\mathrm{X}$ is the elements especially alkali metal that can react with acids such as chloride, sulfate, nitrate, and fluoride acid. But, there are other elements such as aluminum, silicon, iron and calcium that bonded and formed lepidolite. These elements will also react with sulfate acid during the leaching process [2]. This affects the metallic elements in lepidolite that are dissolved to the filtrate. It is proved that the concentrations of aluminum and iron in Tables 3,7 reduced sharply from 51.60 to $24.39 \mathrm{ppm}$ and 49.85 to $15.35 \mathrm{ppm}$, respectively. In addition, acid leaching with sulfate acid will affect lepidolite, which reacted partially and formed two kinds of sulfates, namely alkali metal sulfate and aluminum sulfate [2]. This causes a low concentration of alkali metal and aluminum in the residue. It is proved by ICP analysis of the residue in Table 7 that aluminum concentration is only $24.39 \mathrm{ppm}$ and sodium concentration is only $15.66 \mathrm{ppm}$. Table 7 shows that calcium concentration has the highest value that is $168.54 \mathrm{ppm}$. It is confirmed in Table 6 that calcium compounds in the form of anorthite also have the highest content that is $36.5 \%$. On the other hand, the compound that has the lowest content based on Table 6 is albite with the content of $8.7 \%$.

The leaching process with acid on roasted mica schist also leads to a decrease in potassium concentration. Tables 3,7 show that the potassium concentration decreased from 42.67 to $29.92 \mathrm{ppm}$ while magnesium concentration decreased from 44.56 to $17.30 \mathrm{ppm}$. This indicates that there were potassium element and magnesium element that dissolved to the solution from the leaching process. On the other hand, other compounds increased due to the acid leaching process. Calcium concentration increased from 133.19 to $168.54 \mathrm{ppm}$ while silica concentration increased from 12.2 to $23.07 \mathrm{ppm}$. This is caused by the dissolution of other elements to the solution so other elements that are harder to dissolve with sulfuric acid become concentrated in the residue.
The limitations of this study are the low lithium concentration in raw material, no variations in acid concentration and leaching temperature. The disadvantage of this study was the absence of variation of sulfuric acid concentration in the leaching process. This causes the lithium extraction percentage to be still lower than $100 \%$. Nevertheless, the lithium extraction method in this study can be used as a reference for further study with some improvement. In addition, this study can also give the knowledge that Indonesia has a local natural resource that contains lithium. Some improvements that can be used in further research are a variation in acid concentration and using a lower ratio of sodium sulfate and lepidolite. The difficulty of variation in sulfuric acid concentration requires higher energy consumption, and the occurrence of reduction dissolution for lepidolite in sulfuric acid is still unclear. The process prior to roasting and leaching should be developed in this study. This is because the lithium concentration in the raw material is very low compared to other raw materials. The froth flotation method is the best method for the beneficiation process because the raw material used in this study was low-grade ores [19].

\section{Conclusions}

1. Mica schist was roasted with sodium sulfate as additives at $700{ }^{\circ} \mathrm{C}$ for 40 minutes. This did not affect the kind of lepidolite in mica schist but improved the reactivity of lepidolite against chemical agents. In addition, the roasting process reduced the particle size of mica schist from $32.17 \mu \mathrm{m}$ to $27.16 \mu \mathrm{m}$.

2 . The best variable of solid/liquid ratio in lithium extraction from lepidolite is 1:5. The effect of the solid/liquid ratio of lithium extraction is that lithium extraction percentage increases along with increasing percent solid. Then, the best variable of leaching time variation in lithium extraction from lepidolite was 30 minutes.

3. The optimum lithium extraction percentage from this study was $97.66 \%$ with the operating conditions: roasting process at $700{ }^{\circ} \mathrm{C}$ for 40 minutes and leaching process using $0.36 \mathrm{M}$ sulfate acid with a solid/liquid ratio of 1:5, leaching time of 30 minutes.

\section{Acknowledgments}

The authors express their gratitude for the financial support of the PRN program from the LPDP Ministry of Finance from Indonesia in 2020 with the contract number 83/E1/PRN/2020.

\section{References}

1. Yan, Q., Li, X., Wang, Z., Wu, X., Wang, J., Guo, H. et. al. (2012). Extraction of lithium from lepidolite by sulfation roasting and water leaching. International Journal of Mineral Processing, 110-111, 1-5. doi: https://doi.org/10.1016/j.minpro.2012.03.005

2. Liu, J., Yin, Z., Li, X., Hu, Q., Liu, W. (2019). Recovery of valuable metals from lepidolite by atmosphere leaching and kinetics on dissolution of lithium. Transactions of Nonferrous Metals Society of China, 29 (3), 641-649. doi: https://doi.org/10.1016/ s1003-6326(19)64974-5

3. Su, H., Ju, J., Zhang, J., Yi, A., Lei, Z., Wang, L. et. al. (2020). Lithium recovery from lepidolite roasted with potassium compounds. Minerals Engineering, 145, 106087. doi: https://doi.org/10.1016/j.mineng.2019.106087 
4. Vieceli, N., Nogueira, C. A., Pereira, M. F. C., Durão, F. O., Guimarães, C., Margarido, F. (2018). Recovery of lithium carbonate by acid digestion and hydrometallurgical processing from mechanically activated lepidolite. Hydrometallurgy, 175, 1-10. doi: https:// doi.org/10.1016/j.hydromet.2017.10.022

5. Luong, V. T., Kang, D. J., An, J. W., Kim, M. J., Tran, T. (2013). Factors affecting the extraction of lithium from lepidolite. Hydrometallurgy, 134-135, 54-61. doi: https://doi.org/10.1016/j.hydromet.2013.01.015

6. Guo, H., Kuang, G., Wan, H., Yang, Y., Yu, H., Wang, H. (2019). Enhanced acid treatment to extract lithium from lepidolite with a fluorine-based chemical method. Hydrometallurgy, 183, 9-19. doi: https://doi.org/10.1016/j.hydromet.2018.10.020

7. Hien-Dinh, T. T., Luong, V. T., Gieré, R., Tran, T. (2015). Extraction of lithium from lepidolite via iron sulphide roasting and water leaching. Hydrometallurgy, 153, 154-159. doi: https://doi.org/10.1016/j.hydromet.2015.03.002

8. Vieceli, N., Nogueira, C. A., Pereira, M. F. C., Dias, A. P. S., Durão, F. O., Guimarães, C., Margarido, F. (2017). Effects of mechanical activation on lithium extraction from a lepidolite ore concentrate. Minerals Engineering, 102, 1-14. doi: https://doi.org/10.1016/ j.mineng.2016.12.001

9. Choubey, P. K., Kim, M., Srivastava, R. R., Lee, J., Lee, J.-Y. (2016). Advance review on the exploitation of the prominent energy-storage element: Lithium. Part I: From mineral and brine resources. Minerals Engineering, 89, 119-137. doi: https:// doi.org/10.1016/j.mineng.2016.01.010

10. Margarido, F., Vieceli, N., Durão, F., Guimarães, C., Nogueira, C. A. (2014). Minero-metallurgical processes for lithium recovery from pegmatitic ores. Comunicações Geológicas, 101, 795-798.

11. Vieceli, N., Nogueira, C. A., Pereira, M. F. C., Durão, F. O., Guimarães, C., Margarido, F. (2016). Optimization of Lithium Extraction from Lepidolite by Roasting Using Sodium and Calcium Sulfates. Mineral Processing and Extractive Metallurgy Review, 38 (1), 62-72. doi: https://doi.org/10.1080/08827508.2016.1262858

12. Kuang, G., Liu, Y., Li, H., Xing, S., Li, F., Guo, H. (2018). Extraction of lithium from $\beta$-spodumene using sodium sulfate solution. Hydrometallurgy, 177, 49-56. doi: https://doi.org/10.1016/j.hydromet.2018.02.015

13. Lalasari, L. H., Rhamdani, A. R., Setiawan, I., Sulistiyono, E., Firdiyono, F., Arini, T. et. al. (2018). Pat. No. P00201810009. Alat pembuatan konsentrat litium berbentuk rumah prisma. No. 2019/04021; declareted: 04.12.2018; published: 14.06.2019.

14. Green, D. W., Perry, R. H. (2008). Perry's Chemical Engineers' Handbook. McGraw-Hill.

15. Natasha, N. C., Lalasari, L. H., Rohmah, M., Sudarsono, J. W. (2018). Ekstraksi Litium dari $\beta$ - Spodumen Hasil Dekomposisi Batuan Sekismika Indonesia Menggunakan Aditif Natrium Sulfat. Metalurgi, 33 (2), 69. doi: https://doi.org/10.14203/metalurgi.v33i2.429

16. Luong, V. T., Kang, D. J., An, J. W., Dao, D. A., Kim, M. J., Tran, T. (2014). Iron sulphate roasting for extraction of lithium from lepidolite. Hydrometallurgy, 141, 8-16. doi: https://doi.org/10.1016/j.hydromet.2013.09.016

17. Salakjani, N. K., Singh, P., Nikoloski, A. N. (2016). Mineralogical transformations of spodumene concentrate from Greenbushes, Western Australia. Part 1: Conventional heating. Minerals Engineering, 98,71-79.doi:https://doi.org/10.1016/j.mineng.2016.07.018

18. Swain, B. (2017). Recovery and recycling of lithium: A review. Separation and Purification Technology, 172, 388-403. doi: https:// doi.org/10.1016/j.seppur.2016.08.031

19. Tadesse, B., Makuei, F., Albijanic, B., Dyer, L. (2019). The beneficiation of lithium minerals from hard rock ores: A review. Minerals Engineering, 131, 170-184. doi: https://doi.org/10.1016/j.mineng.2018.11.023 